\title{
Objetos, imagens e sons: a etnografia de Theodor Koch-Grünberg (1872-1924) ${ }^{1}$
}

Objects, pictures and sounds: the ethnography of Theodor Koch-Grünberg (1872-1924)

Erwin Frank

Resumo: O texto caracteriza teórica e metodologicamente a etnografia de Theodor Koch-Grünberg (1872-1924), antropólogo alemão que fez quatro visitas ao Brasil entre 1896 e 1924 e que se notabilizou pelos trabalhos escritos sobre os índios dos rios Negro e Branco, pelas coleções etnográficas e pelos registros sonoros, fotográficos e cinematográficos realizados em suas expedições. O autor relaciona esses registros documentais com o projeto etnográfico do antropólogo, vinculado à Völkerkunde alemã.

Palavras-chave: Theodor Koch-Grünberg. Etnografia. Völkerkundler. Amazônia. Roraima. Rio Negro.

Abstract: The article characterizes the ethnological theory and method of Theodor Koch-Grünberg (1872-1924), a German anthropologist who made four visits to Brazil between 1896 and 1924, and who was especially noted for his writings about the Indians of the Rio Negro and Rio Branco, and the ethnographic collections, sound recordings, photography and films made during these journeys. The author relates this documentary material with Koch-Grünberg's ethnographic project within the tradition of German Völkerkunde.

Keywords: Theodor Koch-Grünberg. Ethnography. Völkerkundler. Amazon. Roraima. Rio Negro.

Texto originalmente escrito em 2008. Editado por Nelson Sanjad e Nelita Frank. Abstract de Glenn Shepard Jr.

Universidade Federal de Roraima. Boa Vista, Roraima, Brasil (in memoriam).

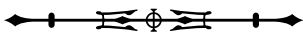


No Brasil, Theodor Koch-Grünberg (1872-1924) é lembrado - principalmente - pelos seus relatos de viagem, nos quais resumiu os resultados de duas das suas quatro visitas a este país: aquela de 1903 a 1905, que o levou à região do alto rio Negro e Yapurá, e a terceira, de 1911 a 1913, na região entre as bacias do rio Branco, no atual Roraima, e os rios Caura, Paráguas e Venturari, na Venezuela². Muitos lembram também que ele foi um incansável colecionador de etnografica ${ }^{3}$, milhares dos quais enchem, ainda hoje, as vitrines e reservas técnicas de vários museus alemães (e do Museu Goeldi). Por outro lado, poucos sabem que foi também um experiente fotógrafo e um dos pioneiros da cinematografia etnográfica, ou que, na sua expedição de 1911-1913, ele gravou inúmeras peças musicais (canções, danças dos povos Macuxi, Taurepang, Wapishana e Maiongong [Yekuana]) em um gramofone trazido da Alemanha ${ }^{4}$.

Desafortunadamente, parte dos resultados do trabalho de documentação etnográfica de Koch-Grünberg no Brasil não sobreviveu ao tempo. Dos diversos rolos de filme que gravou em 1911-1913, por exemplo, meros 15 minutos resultaram ainda aproveitáveis quando, nos anos 1960, Otto Zerries os editou para o Instituto de Filmagem Científica de Göttingen. E dos 50 cilindros de gravações musicais que, em 1991, o fim do 'bloco' socialista trouxe de volta ao Museu Etnológico de Berlim, somente 30 peças, com um total de 50 minutos de gravação, podiam ainda ser digitalizados ${ }^{5}$.

Ora, ninguém sabe ainda o número de etnografica que sobreviveu às - só parcialmente bem sucedidas tentativas dos responsáveis por diversos museus alemães, seus proprietários, de salvá-los dos bombardeios da Segunda Guerra Mundial. Por outro lado, a maior parte das fotografias de Koch-Grünberg sobreviveu ao tempo. Ironicamente, porque o etnólogo nunca abriu mão delas. Dez anos atrás, uma neta de Koch-Grünberg as doou (junto com os diários e a extensa correspondência dele) ao Departamento de Antropologia da Universidade de Marburg, onde estão acessíveis aos interessados.

Contudo, não escrevemos este ensaio para lamentar as perdas que o enorme acervo documental acumulado por este Völkerkundler no Brasil já sofreu, e sim para refletir sobre a razão (o projeto etnográfico/antropológico que está por detrás) da sua acumulação inicial. Procuraremos uma resposta a uma pergunta simples: por que (ou para que) Koch-Grünberg gastou tanto tempo e energia (e boa parte do seu 'gênio' como viajante científico) em tão ampla documentação das suas experiências na Amazônia? Por que, sobretudo, ele achou necessário, às vezes, filmar, fotografar, esboçar à mão e ainda descrever detalhadamente (nos seus diários, em cadernos temáticos e, novamente, nas suas publicações) os mesmos objetos, as mesmas pessoas, as mesmas situações ou eventos e, no caso dos objetos etnográficos colecionados, ainda comprálos e encaminhá-los para a Alemanha?

Tais perguntas podem parecer ingênuas, afinal, este Völkerkundler era etnógrafo tanto de paixão como de profissão; ou seja, fazer o que ele fez foi justamente aquilo que sustentou sua vida e construiu a sua carreira (afinal, Koch-Grünberg não foi o único Völkerkundler que, ao longo de expedições, anotou observações em diários e cadernos temáticos, fotografou, filmou, esboçou e colecionou etnografica).

Porém, levantamos as perguntas justamente com o intuito de (entre outros) contrariar uma resposta

\footnotetext{
2 Koch-Grünberg visitou o Brasil pela primeira vez entre 1898 e 1900, como membro da mal sucedida expedição de Hermann Meyer ao norte do Mato Grosso (aliás, como responsável pela documentação fotográfica), e a última vez em 1924, ano em que faleceu em consequência de um fulminante ataque de malária enquanto esperava a chegada de Hamilton Rice, chefe de uma expedição que tinha o objetivo de descobrir a fonte do rio Orenoco, em Vista Alegre, perto de Caracaraí, Roraima (Kraus, 2004, p. 35-36).

3 E não somente etnografica! Ele também encaminhou à Alemanha amostras minerais e até de fauna (mariposas) e flora das regiões visitadas.

4 Em 2006, o Museu Etnológico de Berlim, 'herdeiro' do Arquivo Fonográfico berlinense (fundado em 1893, onde Koch-Grünberg depositou as suas gravações), lançou uma coleção digitalizada destas peças musicais (Koch-Grünberg, 2006a) [Nota dos Editores: ver, ainda, Galucio, 2009].

5 Neste ponto, $\mathrm{O}$ autor tinha a intenção de inserir referência bibliográfica (Nota dos Editores).
} 
claramente equivocada a elas, implícita em alguns trabalhos historiográficos recentes ${ }^{6}$, segundo os quais a etnografia de Koch-Grünberg (e dos demais Völkerkundler) nunca passou de um exercício 'museológico' a serviço de interesses pouco (ou nada) 'científicos'. Até há quem defenda que os Völkerkundler não eram etnógrafos de verdade, mas, uma espécie de "colecionadores profissionais" disfarçados de etnógrafos, não obstante as inúmeras declarações explícitas em sentido contrário que podem ser encontradas nas publicações e outros escritos deles.

Não há como negar o fato de que a grande maioria dos Völkerkundler passou toda ou, pelo menos, a maior parte da vida e da carreira estreitamente 'vinculada' a museus etnológicos que, em alguns casos, até financiaram as suas expedições. $\bigcirc$ próprio Koch-Grünberg começou a sua carreira no Museu Etnológico de Berlim, onde trabalhou inicialmente como estagiário (isto é, sem remuneração) e, posteriormente (até 1909), como 'Wissenschaftlicher Hilfsarbeiter' (talvez, 'Assistente'). Após seis anos no Departamento de Etnologia da Universidade de Freiburg (dos quais ele passou quase três liberado para a sua expedição ao rio Branco ${ }^{7}$ ), ele voltou para um museu, como Diretor Científico do Museu Linden, em Stuttgart (1915-1924). Enquanto funcionário do museu berlinense, Koch-Grünberg planejou e realizou a sua primeira expedição ao norte da Amazônia, façanha ainda financiada (pelo menos em parte) por aquele museu. Mas, nem por isso ele viajou a serviço daquele museu ${ }^{8}$, e menos ainda ele realizou aquela façanha meramente (nem principalmente) para colecionar etnografica.

Éverdade que, no final das duas principais expedições, ele encaminhou coleções para a Alemanha compostas por milhares de peças. Contudo, como o próprio KochGrünberg esclarece:

\begin{abstract}
(...) para mim, o objetivo principal da minha viagem não era o de um colecionador. Frequentemente demorando-me semanas, até meses em cada tribo, e em cada aldeia, participando intimamente da vida dos indígenas, eu pretendia essencialmente conviver e aprofundar mais a visão das suas concepções, pois o visitante que passa rapidamente pela região de suas pesquisas consegue apenas impressões passageiras e frequentemente falsas (Koch-Grünberg, 2006b, p. 7) .
\end{abstract}

Não é somente no caso de Koch-Grünberg que a interpretação da Völkerkunde como projeto (meramente ou principalmente) 'museológico' não se sustenta à luz dos fatos. Para começar, a dúzia de museus etnográficos que abriu as portas dos últimos anos da década de 1860 em adiante foi (quase toda) uma iniciativa dos Völkerkundler, já reconhecidos como tais ${ }^{10}$.

É bem conhecido, por exemplo, o papel decisivo de Adolf Bastian na formação dos museus de Berlim e Munique. Mas, este e outros Völkerkundler da época atuaram também em posições de destaque nas comitivas organizadoras de outros museus grandes (como em Leipzig e Hamburgo) e menores (como em Colônia, Bremen, Stuttgart etc.), que pipocaram nas cidades alemães na década de 1870. Ora, ao contrário da opinião de alguns, há de se enfatizar que os Völkerkundler não 'criaram' museus por falta de acesso a outros contextos institucionais, como os departamentos universitários. Eles criaram museus porque os consideravam mais propícios para o seu projeto antropológico!

Nada melhor para ilustrar este fato do que a famosa resposta (negativa) de Karl von den Steinen, um dos

\footnotetext{
6 Neste ponto, o autor inseriu uma nota de rodapé, mas não indicou quais autores considerava "anti-Völkerkundler" (Nota dos Editores).

7 Aliás (mesmo que, em base do que segue, é quase desnecessário mencioná-lo), também o Departamento de Etnologia da Universidade de Freiburg tinha (e tem ainda) um pequeno museu etnográfico anexo, ao qual Koch-Grünberg acabou doando várias peças.

8 Entre abril de 1904 e julho de 1905, enquanto viajava pelo Brasil, o seu contrato com o museu ficou temporariamente suspenso.

9 Como já vimos, Koch-Grünberg realizou a expedição de 1911-1913 como 'Privatdozent' (professor sem 'vaga') do Departamento de Etnologia da Universidade de Freiburg. Novamente, a maior parte dos mais de dois mil etnografica acabou no museu de Berlim. Mas não havia nenhum contrato neste sentido, anterior à sua saída. Deveríamos, talvez, mencionar novamente que Koch-Grünberg também colecionou borboletas, plantas e amostras geológicas ao longo da sua viagem.

10 Neste ponto, o autor tinha a intenção de inserir referências bibliográficas (Nota dos Editores).
}

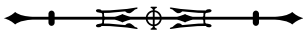


principais representantes da escola na virada do século XIX para o século XX (e, como vimos, superior direto, mas também orientador e amigo de Koch-Grünberg no museu de Berlim), ao convite da Universidade de Marburg para ocupar uma cátedra em Völkerkunde, criada especificamente para ele. Na sua resposta, von den Steinen lembrou inicialmente que, em Marburg, não havia ainda nenhum museu, para então concluir apoditicamente: "Ohne Museum geht's nicht!" ("Sem museu, não há como!")"1. Aquilo que Karl von den Steinen considerava impossível realizar sem acesso a algum museu etnológico foi, é claro, não somente ensinar antropologia, mas praticar a Völkerkunde, isto é, ser e trabalhar como Völkerkundler!

Mas, por que não? Por que essa 'obsessão' de (quase) todos os Völkerkundler para com o museu? O que tanto Karl von den Steinen, como também Theodor Koch-Grünberg (que renunciou ao cargo de professor de etnologia em Freiburg para ocupar a direção científica do Museu Linden, em Stuttgart), encontravam de tão substancial e irrenunciável naquele contexto institucional particular?

Uma resposta a estas perguntas só pode ser encontrada em uma cuidadosa revisão do projeto científico da Völkerkundler em geral, do qual a coleção de etnografica (e os museus onde estará estocada e exposta) constituiu parte integral. Trata-se de um projeto deveras antropológico; porém, a serviço de uma antropologia bem distinta, tanto daquela das demais 'escolas nacionais' da época (como os evolucionistas ingleses e norte-americanos ou os 'sociólogos' franceses) como também daquela praticada pela grande maioria dos antropólogos atuais.
Este projeto, pois, se fundamentava em um entendimento da natureza do 'homem' e da 'cultura', derivada da filosofia (anti-iluminista) alemã de Herder'², dos românticos e dos filósofos idealistas alemães do século XIX, sem esquecer também a influência decisiva dos irmãos von Humboldt ${ }^{13}$. Mas, neste ensaio, nossa aproximação a esse projeto não se fundamentará na exegese de qualquer texto programático destes filósofos e nem dos próprios Völkerkundler. Não porque inexistam tais textos ${ }^{14}$, mas, principalmente, porque eles são, na atualidade, na sua ampla maioria, de difícil acesso no Brasil, e também de difícil entendimento para leitores não familiarizados com a visão filosófica que os norteava ${ }^{15}$.

Em vez disso, procuraremos reconstruir o projeto da Völkerkunde com base em uma leitura aprofundada da mesma praxe etnográfica dos Völkerkundler, tomando a etnografia de Theodor Koch-Grünberg com exemplar. Tentaremos, pois, identificar a razão da praxe (etnográfica) de Koch-Grünberg (e dos demais Völkerkundler) a partir da análise do que este Völkerkundler efetivamente realizou nas suas expedições, ou seja, do material (ou acervo documental) que suas diversas atividades no campo geraram e que ele nos deixou.

É claro que o 'produto' principal do trabalho etnográfico de Koch-Grünberg em campo são os seus dois relatos de viagem, obras primas do gênero, publicados, respectivamente, em 1909-1910 ("Zwei Jahre unter den Indianer") e de 1916 a 1926 ("Vom Roraima zum Orinoco"). Porém, os dois livros (e suas dezenas de outras publicações) não constituem o único 'resultado' do seu trabalho à nossa

\footnotetext{
11 Neste ponto, o autor tinha a intenção de inserir referências bibliográficas (Nota dos Editores).

12 Neste ponto, o autor tinha a intenção de inserir referência bibliográfica (Nota dos Editores).

13 Neste ponto, o autor tinha a intenção de inserir referência bibliográfica (Nota dos Editores).

14 Na realidade, a ampla maioria das (inúmeras!) publicações do 'fundador' desta escola, inspirador e seu principal representante durante décadas, Adolf Bastian, é programática. Só que (além de difícil leitura até para alemães), atualmente, elas estão quase por completo esquecidas [Nota dos Editores: neste ponto, o autor tinha a intenção de fazer referência a algumas obras de Bastian].

15 Principalmente os textos de Adolf Bastian são, em grande parte, mais filosóficos do que propriamente antropológicos, e a sua leitura e entendimento se torna particularmente dificultada pela linguagem muito pessoal que ele achava necessário criar para poder expressar o que considerava importante. Sobretudo após 1880, os seus textos se tornaram praticamente ilegíveis, até mesmo para pessoas com o alemão como língua materna e um profundo conhecimento do fundo filosófico com o qual este autor se comunicava constantemente. Vide Buchheit (2005), quem, afinal, não encontrou melhor maneira de lidar com o pensamento de Bastian que o de segui-lo no interior do seu labirinto semântico; e, para uma análise mais concisa, Fiedermutz-Laun (1970).
}

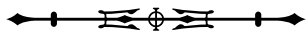


disposição. Além das publicações, há (sobretudo) as quase 4.000 peças de etnografica que Koch-Grünberg colecionou e encaminhou para a Alemanha; há os diários e cadernos de anotações, atualmente guardados em Marburg; há os filmes e as peças musicais da expedição ao norte de Roraima e ao sul da Venezuela, além de milhares de fotografias, desenhos e mapas, dos quais somente alguns poucos foram reproduzidos nas suas obras.

Ora, revisando o total desta produção, impressionante tanto em termos quantitativos como em qualitativos, a primeira conclusão que se impõe é uma verdadeira obsessão pela documentação etnográfica, uma enorme vontade de fixar a própria experiência em notas, fotos, filmes, gravações fonográficas e esboços, que superavam - amplamente! - o comum, tanto na sua época como na etnografia atual.

Por certo, são raros os etnógrafos (desconheço exemplos entre os Völkerkundler!) que não tenham usado a máquina fotográfica (e, atualmente, o gravador) e que não tenham anotado habitualmente as suas observações em diários e cadernos temáticos. Muitos etnógrafos também realizaram filmagens e alguns até esboçaram e elaboraram mapas. Finalmente, pelo menos todos os Völkerkundler colecionaram etnografica ao longo das suas expedições. Mesmo assim, o que impressiona em Koch-Grünberg é a extensão (e o detalhamento) dos seus diários e das suas anotações, a quantidade de fotos que tirou, o número e a variedade de objetos que colecionou (e logrou encaminhar para a Alemanha) e a facilidade com que sempre adotou novas tecnologias, até máquinas pesadas e difíceis de manejar (e manter funcionando) no interior da Amazônia.
Finalmente, impressiona também a quantidade e variedade dos produtos deste esforço documental (fotos, esboços, transcrições de mitos e canções etc.) que o etnógrafo incluiu (achou preciso incluir!) nas suas obras publicadas $^{16}$, para não falar do uso amplo, constante e variável que ele fez deste material nas inúmeras palestras que costumava ministrar em escolas, clubes e programas de educação de adultos.

Sem dúvida, para Koch-Grünberg, o trabalho de campo era, em primeiro lugar, um trabalho de documentação, no sentido mais amplo imaginável, e fora do comum, tanto na sua época como hoje.

Então, o que havia em seus objetos de estudo que precisava ser documentado com tanta urgência? E, sobretudo, para quê? No que segue, procuraremos uma resposta a esta questão centrando (inicialmente) na obra fotográfica de KochGrünberg, principalmente aquelas fotografias que ilustraram as suas diversas publicações. Revisaremos esta produção fotográfica norteados por uma pergunta simples: afinal, o que este Völkerkundler fotografou mesmo ${ }^{17}$ ?

\section{A OBRA FOTOGRÁFICA DE KOCH-GRÜNBERG}

Para começar, paisagens são (relativamente) raras nesta obra fotográfica. As fotos (ainda mais raras!) que, afinal, ele incluiu nas suas publicações são, quase sempre, ilustrações das condições de trabalho do etnógrafo (principalmente, as dificuldades de transporte, o acampamento no interior etc.) ou vistas de pontos estratégicos da expedição, como Manaus, São Gabriel, São Marcos etc. (Figura 1) 18. $^{18}$ Em algumas destas fotografias, pessoas aparecem; com

${ }^{16}$ Daí lamentarmos sobremaneira a decisão do comitê editorial responsável pela publicação recente da tradução do primeiro volume de "Vom Roraima zum Orinoco" de - sem qualquer aviso - eliminar daquela publicação $50 \%$ das fotografias do original, parte integrante do projeto editorial original de Koch-Grünberg.

17 Não vamos comentar nada, neste ensaio, sobre a estética do trabalho de Koch-Grünberg como fotógrafo (ou cineasta). Sem dúvida, há muitas fotografias de excepcional beleza e cuidadosa composição, mostrando um entendimento claro do autor com relação às dimensões deste tipo de trabalho, além do puramente documental. Mas, estas dimensões não importam aqui. $\bigcirc$ que importa é o uso que Koch-Grünberg fez da câmera como instrumento de documentação etnográfica, de congelamento instantâneo (e transformação num objeto transportável: uma placa de vidro) daquilo que ele tinha frente aos próprios olhos, no alto rio Negro e em Roraima.

18 Nas savanas do rio Branco (mas não na selva do rio Negro), também certos elementos estranhos ou extraordinários da paisagem (para um alemão, é claro) são registrados, como galerias da palmeira buriti, certas formações rochosas, formigueiros gigantes etc., assim como o Monte Roraima, é claro. 


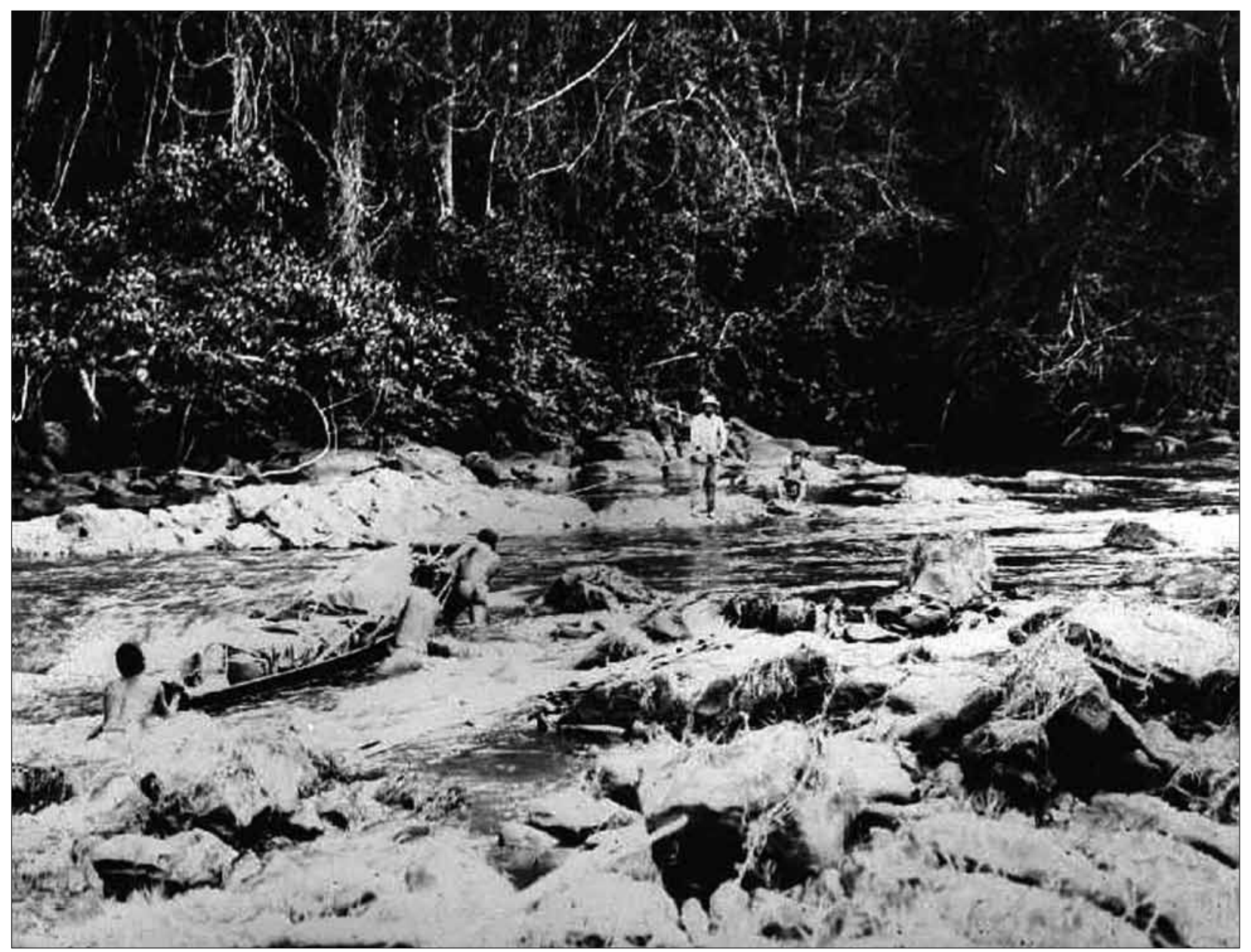

Figura 1. Nachlass Theodor Koch-Grünberg, Völkerkundliche Sammlung der Philipps-Universität Marburg/Legado Científico de Theodor Koch-Grünberg, Coleção Etnográfica da Universidade Philipps de Marburg. Inventarnummer/Número de inventário: KG-H-III,104d.

frequência, o próprio fotógrafo, a sós ou rodeado por indígenas. Nestes casos, trata-se, obviamente, de mostrar tipos de interação etnográfica, como: "índios viajando com o etnógrafo [carregando a sua equipagem]'; 'indios observando o etnógrafo trabalhar'; 'índios informando' etc'19. Mas, não há dúvida, ilustrar paisagens ou o nativo no seu contexto natural não era o interesse principal deste etnógrafo como fotógrafo, pois, a ampla maioria das suas fotografias mostra objetos etnográficos ou algum nativo, individual e descontextualizado.

Há (literalmente) centenas de fotografias mostrando índios (ou índias) retratados não como indivíduos (o índio $X$ ), mas como exemplares ou tipos (Figura 2) ${ }^{20}$. Nestas fotos, qualquer referência ao contexto é eliminada. A

19 A finalidade deste tipo de fotografia parece ser demonstrar o esforço etnográfico no seu contexto natural, como também a própria natureza da etnografia: contato e interação íntimos (corporal) e constantes para com nativos.

20 Neste ponto e em outros assinalados ao longo do texto, o autor tinha a intenção de incluir fotografias, mas não foi possível identificar quais, entre as várias que mandou reproduzir no Departamento de Etnologia da Universidade de Marburg. A escolha de todas as fotos presentes neste trabalho foi dos editores (Nota dos Editores).

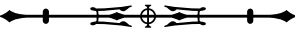




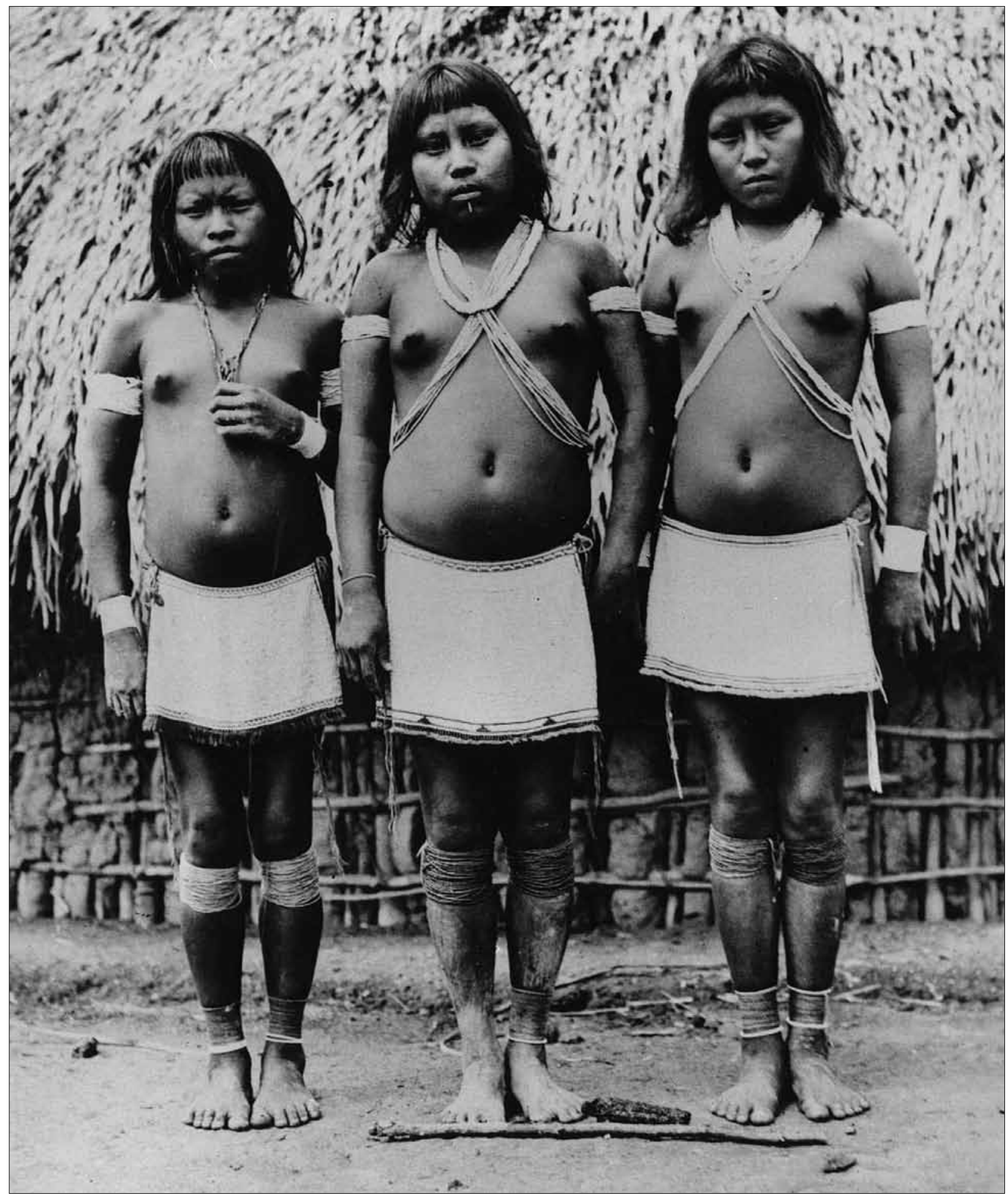

Figura 2. Nachlass Theodor Koch-Grünberg, Völkerkundliche Sammlung der Philipps-Universität Marburg/Legado Científico de Theodor Koch-Grünberg, Coleção Etnográfica da Universidade Philipps de Marburg. Inventarnummer/Número de inventário: KG-H-III,192d. 
maioria tem como fundo um tecido branco e, às vezes, parece que o fundo foi, posteriormente, eliminado via retouch. As pessoas fotografadas (em geral, de frente e de perfil; de corpo inteiro ou da cintura para cima) foram claramente posicionadas: braços para baixo, cabeça para cima, nenhum sorriso, o olhar fixado na câmera ou em algum ponto distante, à esquerda ou à direita. Nenhuma individualização é pretendida, até mesmo nos - raros casos nos quais os títulos das fotografias indicam os nomes das pessoas retratadas; porém, na maioria dos casos, as pessoas retratadas são identificadas somente pelo nome do seu grupo étnico.

O 'objeto' destas fotografias é, claramente, o próprio corpo indígena. Ou seja, aquilo que Koch-Grünberg quis mesmo documentar é, sem dúvida, a constituição biofísica e postura, a forma das cabeças, as variações faciais, os 'estilos' de penteado e, eventualmente, os ornamentos e as vestimentas tradicionais.

Faltam sinais do contato em andamento com a sociedade não-indígena (vestimenta ocidental, artefatos), e parece até provável que eles foram cuidadosamente retirados nos momentos preparativos à tomada das fotografias. Por outro lado, sinais da 'indianidade' dos retratados (como os ornamentos tradicionais) são frequentes; às vezes, até enfatizados (por exemplo, explicitamente apontados no título da foto ou no texto que a acompanha), ao ponto de que, em alguns casos, as pessoas parecem ser meros manequins para apresentar o contexto natural do uso que os nativos faziam de certos ornamentos, instrumentos ou armas tradicionais.

Isto nos leva à segunda categoria mais frequente na obra fotográfica de Koch-Grünberg. Trata-se de fotos que mostram peças da cultura material dos indígenas visitados: objetos fabricados pelos índios, fotografados um por um ou - com menos frequência - em grupos do mesmo tipo ${ }^{21}$. Na maioria destas fotos, o fundo é (novamente) um tecido branco ${ }^{22}$, e o mesmo objeto pode aparecer, às vezes, em duas ou mais fotografias distintas, tomado de vários ângulos. Material e detalhes técnicos de fabricação são destacados, mas raramente o seu uso (em geral, detalhado nos textos ou em esboços esquemáticos). Há, ainda, outro tipo ou categoria de fotografias, que classificamos como 'indígenas em ação', nas quais alguns destes objetos aparecem em uso.

Esta terceira categoria mostra nativos (individualmente ou em grupo) realizando certas tarefas ou rotinas, como caçar (com a zarabatana), processar comestíveis, jogar, dançar etc. (Figuras 3 e 4). Aqui, a postura e os aspectos técnicos da ação são enfatizados, e o contexto da foto (o interior ou a área em frente da casa), às vezes, até parece destacado. Frequentemente, a ação em questão é documentada em toda uma sequência de fotografias, tomadas do mesmo ou de ângulos diversos.

É preciso constatar, neste contexto, que, na expedição de 1911-1913, Koch-Grünberg documentou, com frequência, as mesmas atividades, filmando e fotografando; e que todas as atividades (e objetos usados), assim duplamente documentadas, ainda são minuciosamente descritas nas diversas publicações do etnógrafo. Este fato parece sugerir que o etnógrafo considerava a documentação meramente uma técnica (não importa qual), intrinsecamente insuficiente; ou seja, para ele, havia aspectos na ação filmada, fotografada, descrita e, às vezes, esboçada à mão, que somente uma das técnicas de documentação podia captar adequadamente ${ }^{23}$.

Finalmente, há, ainda, o que chamamos de fotos de 'grupos de índios', mostrando, por exemplo, todos os habitantes de certa aldeia (geralmente identificada),

\footnotetext{
21 Neste ponto, o autor tinha a intenção de inserir uma figura, mas não foi possível localizá-la ou identificá-la (Nota dos Editores).

22 Há de se enfatizar, neste contexto, que quase a totalidade dos objetos fotografados acabou fazendo parte das extensas coleções que KochGrünberg encaminhou para a Alemanha. Frequentemente, não é mais possível distinguir as fotos de objetos tomadas ainda no campo, de outras tomadas somente depois, no museu.

${ }^{23}$ Também não se trata meramente de uma medida de segurança, já que parece que muitos dos esboços, por exemplo, foram efetivamente realizados após a expedição, no laboratório dos museus de Berlim ou Stuttgart, com base nas fotografias.
}

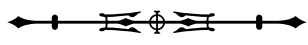




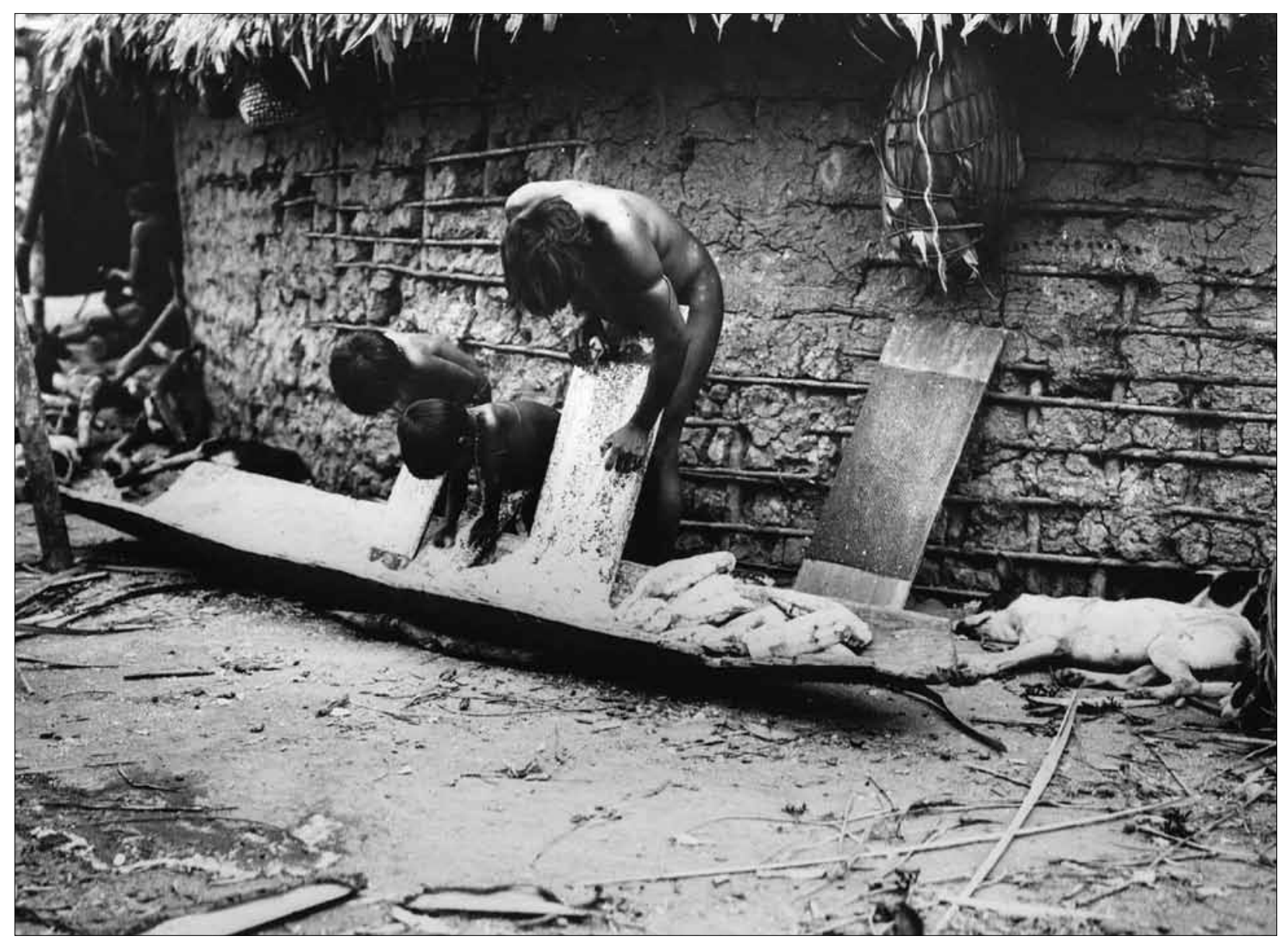

Figura 3. Nachlass Theodor Koch-Grünberg, Völkerkundliche Sammlung der Philipps-Universität Marburg/Legado Científico de Theodor Koch-Grünberg, Coleção Etnográfica da Universidade Philipps de Marburg. Inventarnummer/Número de inventário: KG-H-III,71d.

um grupo de visitantes, a 'família do tuxaua (ou chefe) $X^{\prime}$ ou, ainda, pequenos grupos de homens e mulheres (com maior frequência, crianças) claramente agrupados para serem fotografados em ambientes 'naturais': alguma paisagem ou à frente de uma casa (Figuras 5 e 6).

Não cabe dúvida de que estas fotografias foram tomadas com o consentimento (até mesmo para agradar) as pessoas retratadas (às quais Koch-Grünberg costumava mostrar o resultado ainda no campo). Contudo, a frequência relativa deste tipo de foto, em comparação com os 'índios em ação', pode indicar certas dificuldades técnicas em fotografar pessoas em movimento (pouco provável) ou certa resistência dos indígenas a fotografias tomadas sem consentimento prévio. A frequência de fotografias mostrando crianças e/ou adolescentes (em vez de adultos) também pode ser interpretada como apontando nesta direção (Figura 7).

Resumindo, pois, podemos constatar que, além de algumas outras categorias residuais, o grosso das fotografias de Koch-Grünberg tem meramente dois 'objetos' alternativos: em primeiro lugar, índios - digamos - 'tipificados' e, em segundo lugar, artefatos da cultura material indígena.

Ocorre que, do ponto de vista de um observador atual, justamente a finalidade destes dois tipos de fotografias (e, sobretudo, a sua frequência, assim como a frequência

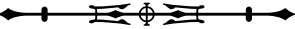




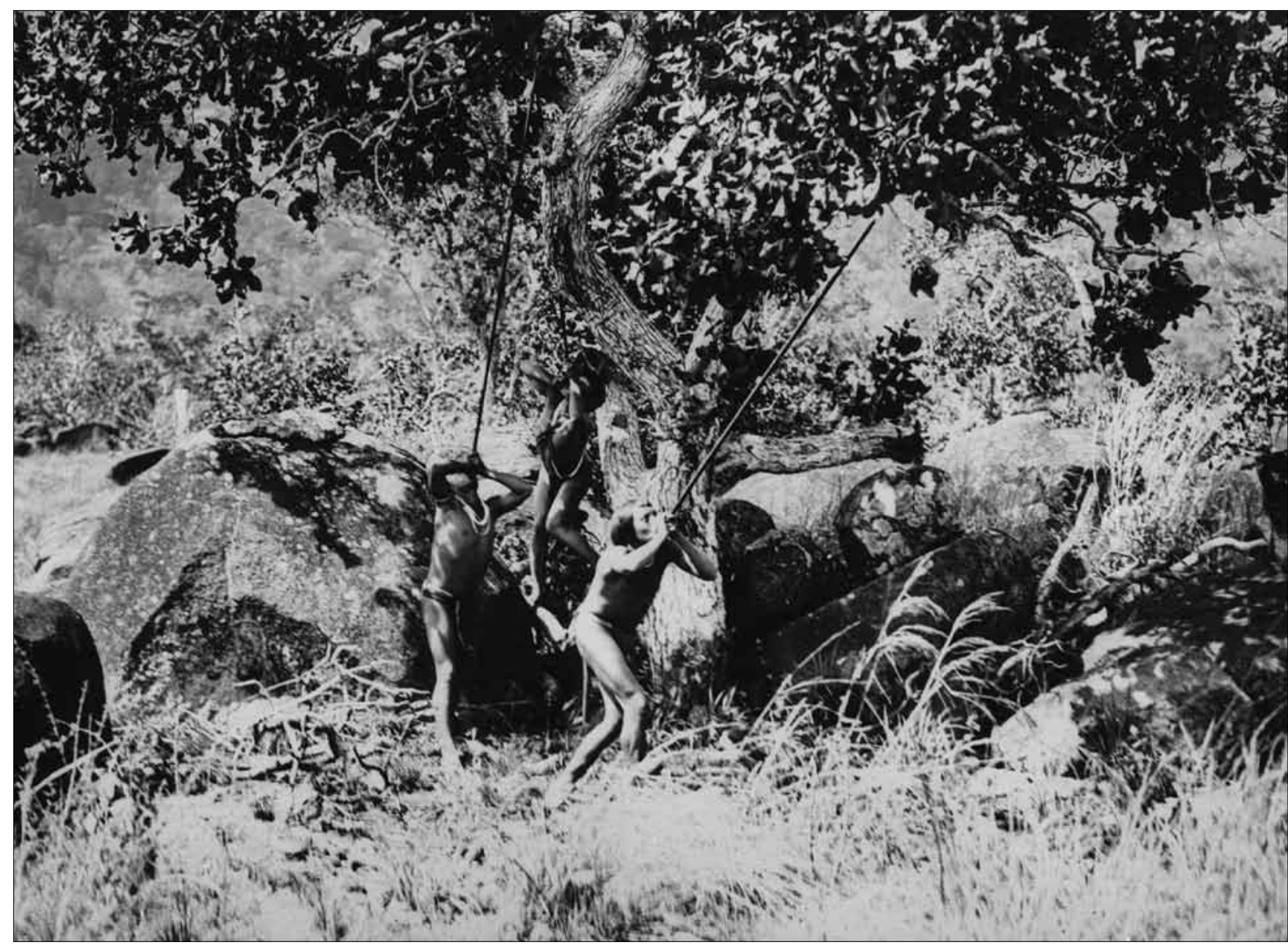

Figura 4. Nachlass Theodor Koch-Grünberg, Völkerkundliche Sammlung der Philipps-Universität Marburg/Legado Científico de Theodor Koch-Grünberg, Coleção Etnográfica da Universidade Philipps de Marburg. Inventarnummer/Número de inventário: KG-H-III,197d.

com a qual elas acabaram reproduzidas nas publicações do autor ${ }^{24}$ ) é pouco clara. Afinal, por que tantas fotos de índios totalmente 'desindividualizados'? E, mais ainda, por que tantas fotos de objetos que, afinal, acabaram, em sua maioria, por fazer parte das coleções que o etnógrafo mandou para a Alemanha?

Com relação à primeira das duas categorias (tipos indígenas ou índios 'típicos', isto é, pessoas

\footnotetext{
${ }^{24}$ Um rápido olhar sobre o acervo de fotografias de Koch-Grünberg, agora no arquivo do Departamento de Etnologia da Universidade de Marburg, dá a impressão de que, eventualmente, nossa avaliação da frequência relativa das diversas categorias de fotos acima indicadas não vale para o acervo fotográfico deste Völkerkundler na sua totalidade, já que parece haver mais paisagens e documentos da vida do etnógrafo no campo do que tipos indígenas e artefatos, categorias que claramente predominam nas suas publicações. A razão disso pode ser editorial, isto é, pode ser que, por alguma razão, Koch-Grünberg tenha considerado tipos indígenas e artefatos de maior importância para o seu leitor, ou que a frequência de, por exemplo, paisagens no acervo de Marburg seja artificial devido ao fato de que o etnógrafo depositou algumas fotos em museus (sem tirar cópias para si) e ficou com aquelas que, do seu ponto de vista, eram de menor interesse científico. De toda maneira, a nossa classificação (e avaliação da importância relativa [numérica] de cada classe) foi elaborada com base nas fotos reproduzidas nas principais publicações deste autor, incluindo, além das duas grandes monografias já mencionadas, as duas "Überarbeitungen" (reedições em tamanho menor, de 1923 e 1934) publicadas para um público distinto (mais jovem) daquele das obras principais, onde, aliás, aumenta o número de ilustrações à mão (esboços) e desaparecem os tipos indígenas [Nota dos Editores: neste ponto, o autor tinha a intenção de incluir as referências bibliográficas das versões populares das obras de Koch-Grünberg].
}

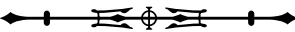




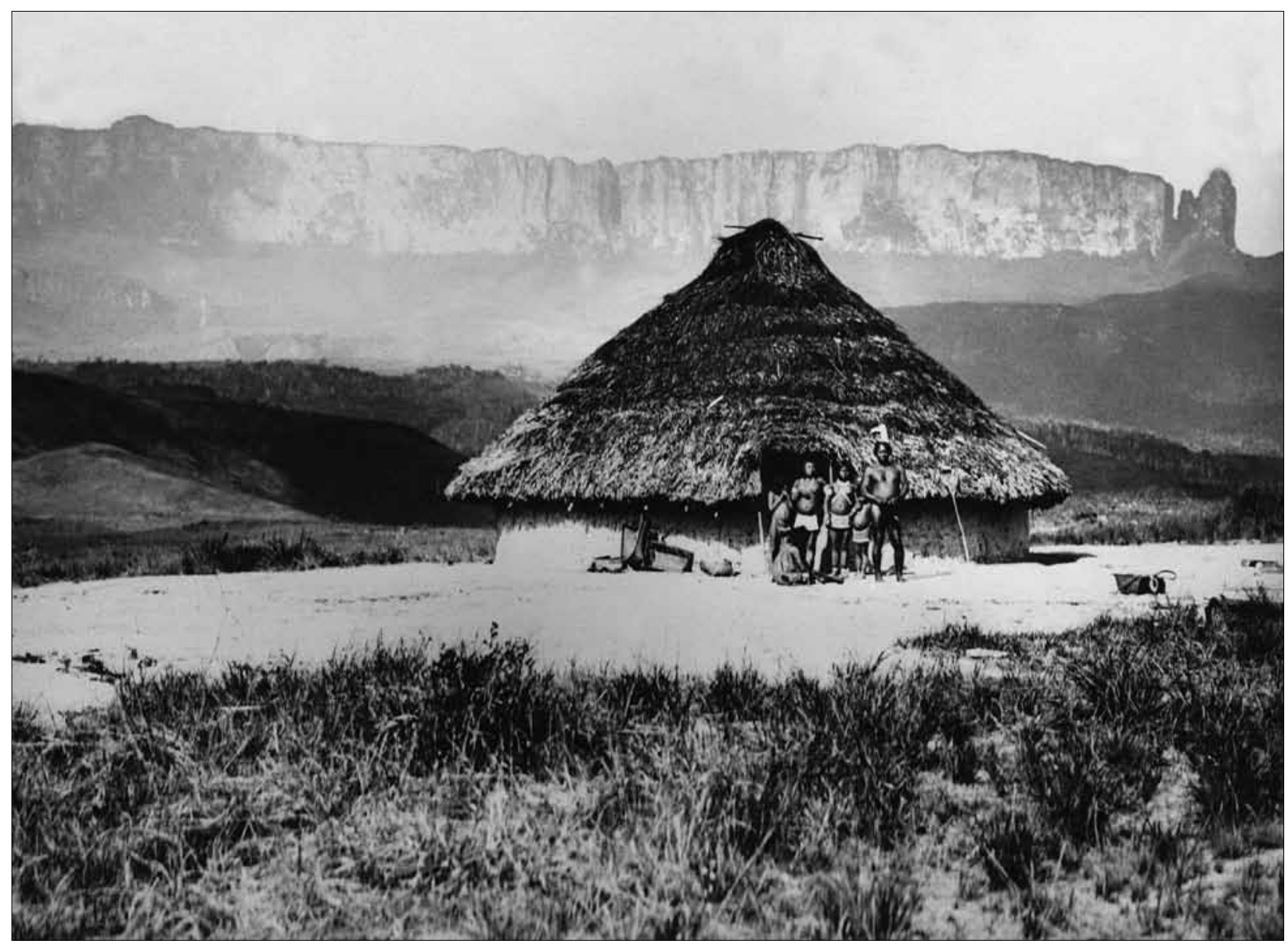

Figura 5. Nachlass Theodor Koch-Grünberg, Völkerkundliche Sammlung der Philipps-Universität Marburg/Legado Científico de Theodor Koch-Grünberg, Coleção Etnográfica da Universidade Philipps de Marburg. Inventarnummer/Número de inventário: KG-H-III,40.

anônimas, fotografadas de frente e de perfil sobre um fundo neutro), não cabe dúvida de que as fotografias foram tomadas (e massivamente reproduzidas nas duas grandes monografias) como contribuição do autor à antropologia física.

Como todos os demais integrantes da sua 'escola', também Koch-Grünberg considerava a antropologia física parte integral da etnologia. Em vista deste fato, até resulta estranho que (ao que parece), no campo este Völkerkundler jamais tenha realizado medições de altura, peso, circunferência do tórax, índices cefálicos etc., e que, nas suas publicações, o alemão tenha se limitado a fazer caracterizações vagas e curtas sobre a aparência dos índios encontrados, como: os X são "pequenos", "fortes", "marrons", "feios" etc.

Acreditamos que Koch-Grünberg tinha uma ideia bastante vaga da antropologia física, que, na sua época, começou a se estabelecer como uma ciência autônoma e a desenvolver metodologias (tanto de levantamento, como de processamento dos seus dados) que a aproximaram, cada vez mais, da medicina. Mas, isto não significa que ele não tenha compartilhado plenamente a convicção (herderiana, básica em toda a sua 'escola') da natureza da cultura humana (ou das culturas humanas, no plural) como produto de uma interação contínua entre, de um lado, a constituição biofísica do homem (que, como em toda a sua

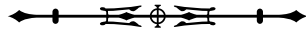




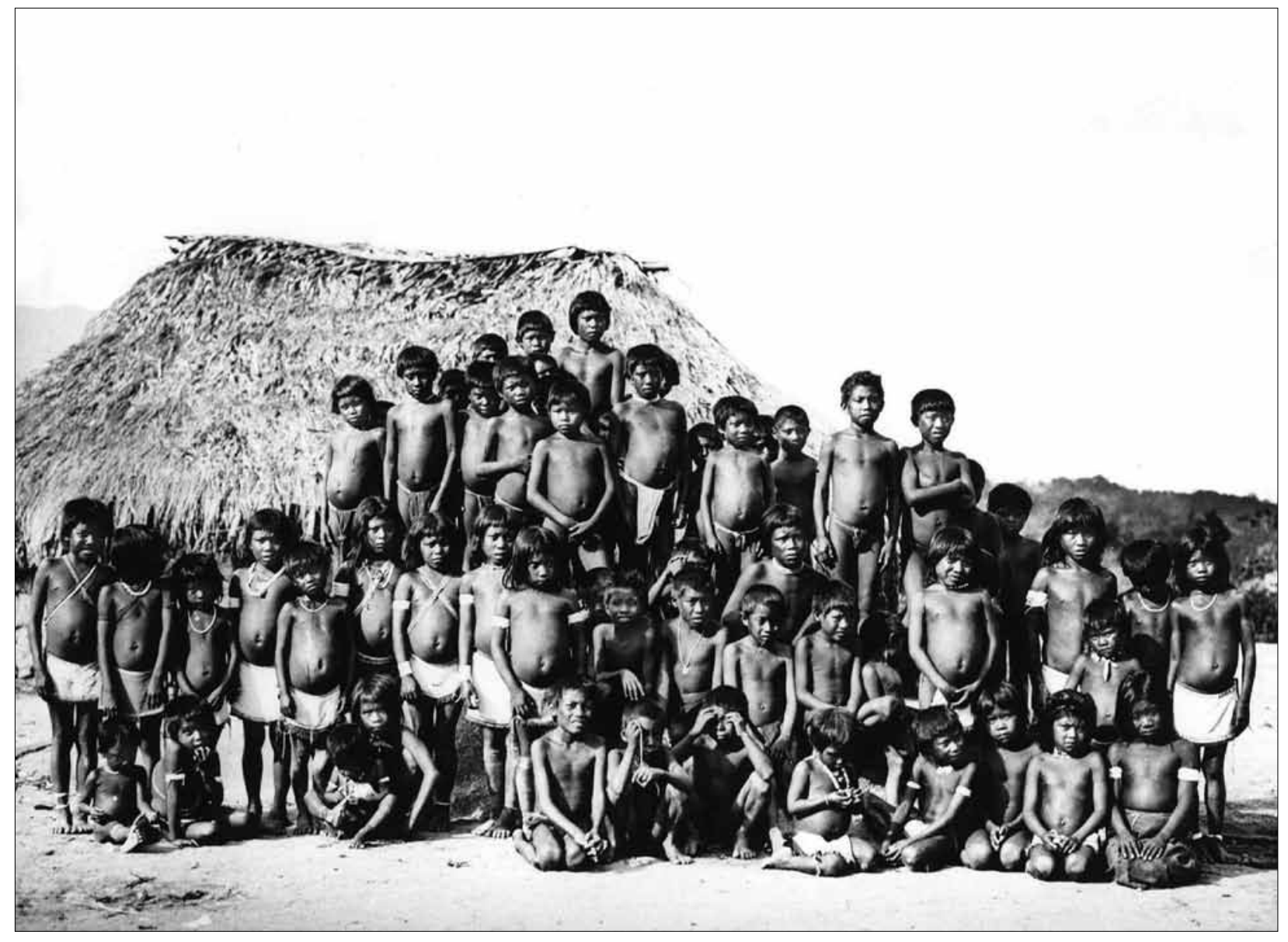

Figura 6. Nachlass Theodor Koch-Grünberg, Völkerkundliche Sammlung der Philipps-Universität Marburg/Legado Científico de Theodor Koch-Grünberg, Coleção Etnográfica da Universidade Philipps de Marburg. Inventarnummer/Número de inventário: KG-H-III,191d.

época, era considerada variável entre 'raças') e, de outro lado, o seu ambiente; uma interação que teria na mente humana o seu locus, mas também um dos seus agentes ${ }^{25}$.

Uma consequência disso parece ser a convicção firme em Koch-Grünberg de que a aparência (o tipo físico e a fisionomia) de qualquer homem (ou melhor, a aparência/fisionomia de todos os integrantes de algum povo, culturalmente constituído) estaria, de alguma maneira, marcada por essa interação. Ou seja, para Koch-Grünberg, 'povos' (Völker) se distinguem entre si não somente pela sua cultura, mas - justamente em consequência da sua especificidade cultural - também na sua aparência, o que seria perceptível por meio da documentação fotográfica de corpos e rostos 'típicos'. Daí o peso numérico de tais fotografias na obra fotográfica deste Völkerkundler, cuja seleção ele

\footnotetext{
${ }^{25}$ Para Herder e os Völkerkundler, a mente humana não era somente um tabula rasa na qual o ambiente e, sobretudo, a cultura momentânea do seu povo se inscreveu ao longo dos primeiros anos de vida de qualquer recém-nascido. Isto porque a mente humana tinha as suas próprias leis, ou, na versão de Adolf Bastian desta doutrina, a mente humana nascia com a pré-inscrição dos famosos Völkergedanken, 'ideias' pré-fabricadas que, historicamente, podiam ser modificadas (segundo ambientes e situações distintas), mas não eliminadas, nem ignoradas [Nota dos Editores: neste ponto, o autor tinha a intenção de inserir referência bibliográfica de obra de Bastian].
}

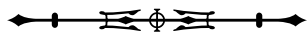




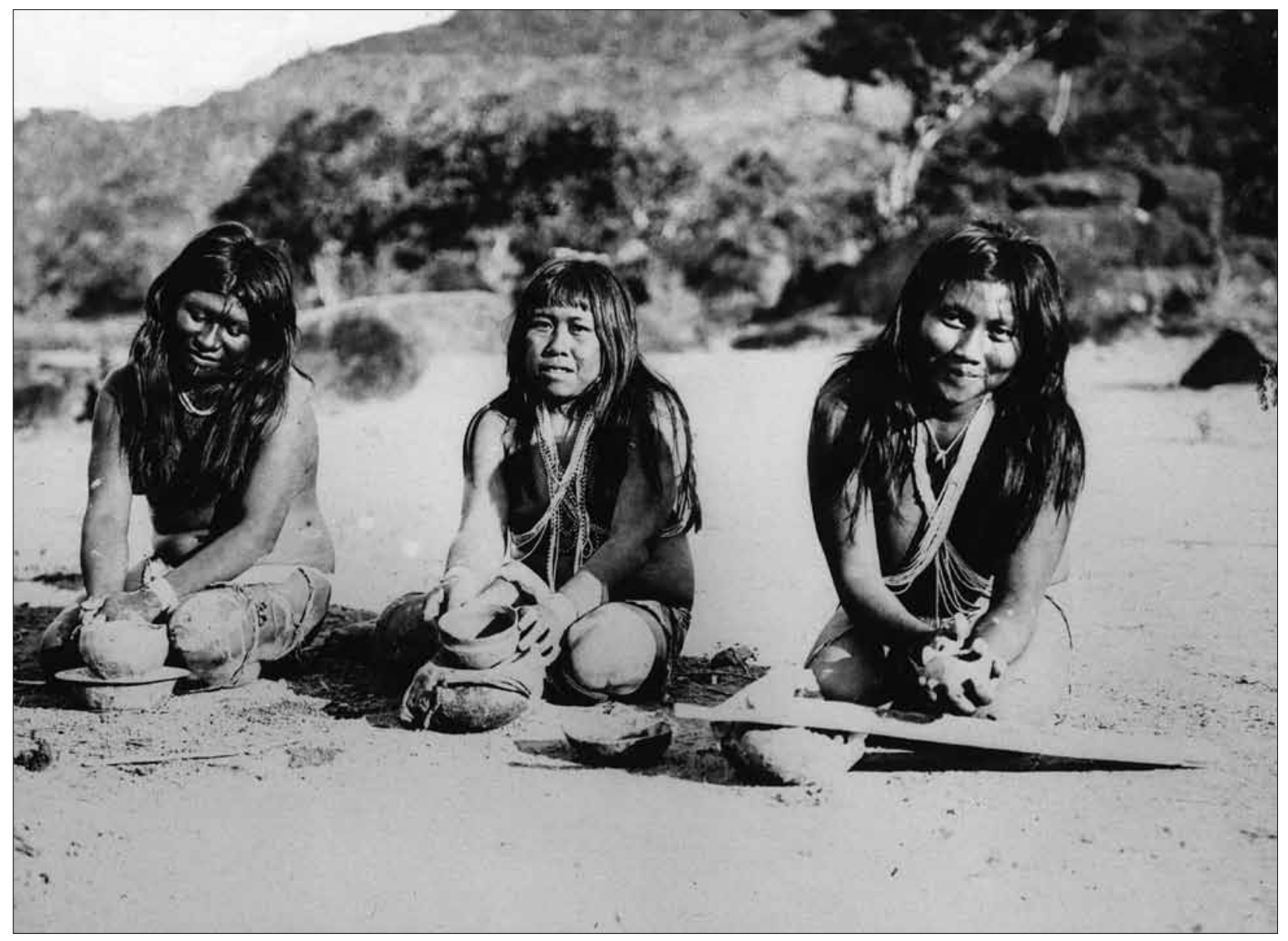

Figura 7. Nachlass Theodor Koch-Grünberg, Völkerkundliche Sammlung der Philipps-Universität Marburg/Legado Científico de Theodor Koch-Grünberg, Coleção Etnográfica da Universidade Philipps de Marburg. Inventarnummer/Número de inventário: KG-H-III,196d.

publicou posteriormente em duas obras que denominou "Typenatlas" ("Atlas de tipos" indígenas), categoria estranha de publicação (sem análise nem comentários, além de não ter paralelo em outros autores). No caso da expedição de 1903-1905 ao alto rio Negro, Koch-Grünberg publicou este atlas em separado, enquanto em "Vom Roraima zum Orinoco", ele constitui o volume cinco.

É preciso lembrar, neste contexto, que, na tradição herderiana, a 'cultura' é meramente outra pré-condição existencial, particular da espécie humana, que somente em conjunto com a sua constituição biofísica poderia explicar a existência e persistência dela neste mundo ${ }^{26}$. Em outras palavras, somente pela incorporação de alguma 'cultura' (ao longo da sua infância e juventude) os seres humanos se transformariam efetivamente de integrantes de uma espécie biofísica, em si mesma e por si só inviável, em membros de uma espécie viável, capaz de sobreviver no mundo. Para Herder, pois, não é a constituição biofísica que sustenta a vida cultural, mas a necessária 'culturalidade' existencial do ser humano que torna a (nossa) espécie imaginável.

É importante enfatizar que nem Herder e nem os Völkerkundler entenderam a incorporação necessária de

\footnotetext{
${ }^{26}$ Neste ponto, o autor tinha a intenção de inserir referência bibliográfica e citação de obra de Herder (Nota dos Editores).
}

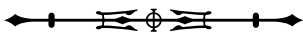


alguma cultura logocentricamente ${ }^{27}$, isto é, como mera aprendizagem (consciente ou subconsciente) de um conjunto de regras e valores culturais, assim como de conhecimentos técnicos de manipulação da realidade (como faz o grosso da antropologia atual, desde as influências decisivas de Saussure e Freud). Para Herder, trata-se de uma verdadeira 'in-corporação', a transformação do próprio corpo humano num instrumento da sua cultura. Daí que, para Herder (e os Völkerkundler), uma vez plenamente 'enculturados', os seres humanos não podem senão expressar a sua identidade cultural adquirida em tudo que fazem, dizem, pensam e sentem. Pois, é a própria natureza cultural de cada integrante de nossa espécie que se expressa em tudo o que faz, diz ou exterioriza de qualquer outra maneira (gestos, mímica), em toda e qualquer ação (ou fala), até mesmo no que não faz ou diz.

Enfim, para Herder e os Völkerkundler, não havia nada observável em um ser humano que não fosse a priori cultural, que não documentasse (igualmente bem, ou de maneira exemplar) uma mesma constituição cultural, o seu pertencimento ao conjunto (histórico e regionalmente circunscrito) de algum 'povo' (Völk) culturalmente constituído ${ }^{28}$.

Eis a razão da tão frequentemente lamentada fixação dos Völkerkundler - enquanto etnógrafos - no visível, no óbvio, nas rotinas, algo mal-interpretado por quase todos os comentaristas como consequência da falta de teoria nesta 'escola', capaz de indicá-los o realmente essencial nas ações dos nativos visitados, concebido como algo por detrás das aparências e obviedades da experiência etnográfica. Para os Völkerkundler (como Koch-Grünberg), a única coisa por detrás do observável nos indígenas visitados é a própria cultura deles, e não qualquer causa ou razão além dela.

Eis também a causa da 'obsessão' dos Völkerkundler (como vimos, particularmente evidente em Koch-Grünberg) pela cultura material. Pois, tratando-se de objetos elaborados por homens e mulheres, 'culturalmente' Tucano, Macuxi ou Mayongong, a mesma cultura destes povos acabou indelevelmente inscrita nos objetos (na seleção da matériaprima, na forma e em qualquer detalhe técnico de fabricação).

Para os Völkerkundler, os objetos etnográficos constituíam mesmo 'cultura materializada', expressões diretas (e não representações) da verdadeira natureza (cultural) dos seus criadores, que, ao contrário das demais expressões dessa natureza (como as [inter]-ações das pessoas e as suas falas), tinham a inestimável vantagem de não perder nada com a separação espacial e temporal do contexto histórico e geográfico da sua origem, isto é, com o seu transporte e a conservação em algum museu na longínqua Alemanha. Pelo contrário, nos museus, os objetos podiam ser vistos, estudados, manipulados, analisados e expostos, para não somente ilustrar, mas reproduzir nas pessoas (devidamente 'preparadas' [gebildet] para tal, é claro) uma experiência da alteridade cultural de povos distantes, em geral reservada ao próprio etnógrafo.

Tratava-se, pois, do tipo de documento mais imediato possível (da verdade) da experiência etnográfica do Völkerkundler, verbalmente, isto é, só aproximadamente, reproduzida (intermediada pela escrita e a retórica) nos seus relatos de viagem (e nas demais publicações especializadas ${ }^{29}$. Daí que o museu etnográfico, longe de

27 Neste ponto, o autor informa que emprestou este termo de obra de Ann Brower Stahl (Nota dos Editores).

${ }^{28}$ Um aspecto extremamente importante (e interessante) disso é que, deste ponto de vista, não pode haver individualidade fora ou (elaborada) contra a cultura. A própria variação individual no interior de um povo é, em si mesma, tão culturalmente constituída como o costumeiro, seguido pela massa dos seus integrantes. É ela mesma costume nos chefes, nos xamãs, nos guerreiros e nos Stutzer, aqueles que tentam se distinguir entre os demais pela beleza dos seus enfeites.

29 Finalmente, há ainda a razão da concentração de quase todos os Völkerkundler no campo da transcrição de mitos, contos, canções (e até de piadas), sempre que possível, na própria língua dos nativos. Ao contrário de outras 'falas', estes eram expressões verbais da cultura formalmente 'congeladas', cuja leitura ou reentonação em espaços e tempos distantes permitiria ao leitor ou ouvinte outra experiência imediata da cultura daqueles que contaram ou cantaram os seus originais. Mais ainda, neste caso específico, o que poderia mesmo ser reexperimentado era a própria mente (coletiva) de um povo em ação; a sua mais pura expressão, pois, intermediada somente pela língua, ela mesma expressão pura da mente histórica do povo observado.

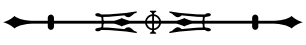


um contexto institucional contra as exigências do qual os Völkerkundler tinham que defender qualquer pretensão deveras antropológica que, por acaso, eles tivessem, foi locus predileto de geração e ampliação de experiências geradoras de qualquer conhecimento etnológicoantropológico de verdade.

As culturas que os Völkerkundler estudaram eram modos concretos de 'estar-no-mundo', mostrados (vividos) por povos distantes e de difícil acesso (além de serem considerados em via de rápida extinção em consequência da expansão agressiva de um deles, a civilização ocidental). Não havia como conhecê-los todos com base em uma experiência imediata (não intermediada). Nesse sentido, o trabalho de campo permitiria a alguns experimentar tais modos de 'estar-no-mundo' pessoalmente. Ora, este privilégio impôs a estes poucos a obrigação moral (sempre que suficientemente formados [gebildet] para tal) de facilitar, a qualquer um que assim desejasse, refazer, ele próprio, na distante Europa, a mesma experiência e, de tal maneira, adquirir o mesmo conhecimento; ou, minimamente, uma experiência (e um conhecimento) maximamente aproximados daqueles do etnógrafo ${ }^{30}$.

Como, aliás, para quase toda a comunidade científica do seu país e da sua época, também para os Völkerkundler qualquer conhecimento era necessariamente fruto de uma experiência. E como também para a (quase) totalidade dos cientistas alemães da segunda metade do século XIX, o conhecimento científico era fruto de experiências depuradas da ignorância (do preconceito e da incapacidade de tirar as conclusões pertinentes) dos homens sem formação (Bildung). Como tal, este tipo de conhecimento não era nada particular ou exclusivo dos cientistas, mas, justamente uma maneira de 'entender o mundo' que diferenciava o homem formado (gebildet; o Bildungsbürger) do 'povão' (homem comum ou ignorante).

Só que a formação deste Bildungsbürger foi entendida como processo, ou seja, como uma tarefa permanente de todos eles. Daí que a etnografia dos Völkerkundler foi também um empreendimento pedagógico de Volksbildung (educação/formação do povo), e não um mero passatempo de alguns especialistas (cientistas). Por isso, os Völkerkundler nunca se dirigiam nas suas publicações exclusivamente aos colegas e aos estudantes de antropologia. $\bigcirc$ público alvo de todo o seu trabalho era sempre aquela parte do povo alemão, na época identificada como Bildungsbürgertum, constituída pela classe de homens (e mulheres) formada nos Gymnasien [ginásios] e nas universidades alemãs ${ }^{31}$.

Contudo, como o conhecimento etnológico era, necessariamente, fruto de uma experiência que, pela própria natureza do seu objeto, só podia ser realizada por uma minoria (os próprios Völkerkundler expedicionários), os métodos por eles aplicados no campo foram cuidadosamente escolhidos, elaborados e testados, sob o aspecto da sua capacidade de gerar uma documentação (no sentido mais amplo deste conceito) capaz de reproduzir no leitor dos seus relatos de viagem, ou no visitante dos museus ou no ouvinte das suas palestras, uma experiência maximamente parecida com aquela do próprio etnógrafo no campo.

Eis a preferência dos Völkerkundler pelo gênero literário dos relatos de viagem. Como declarou o próprio Koch-Grünberg, esperava-se deste gênero que permitisse ao leitor acompanhar a mesma experiência do etnógrafo

\footnotetext{
30 Basta ler - com atenção - a justificativa de Koch-Grünberg publicada no seu relato de viagem ao alto rio Negro: "Neste livro, apresento os resultados científicos a partir da descrição popular da viagem, para que o leitor, através das ilustrações, de certa maneira possa conhecer diretamente a vida dos nativos e, fazendo a viagem junto comigo, adquirir suas experiências" (KochGrünberg, 2005, p. 7). O leitor aqui é, claro, um leigo (daí a o tom da descrição, anunciado como popular). Mas, há de lembrar que, do ponto de vista da Völkerkunde, no seu enfrentamento com algum povo no campo, o etnógrafo é também um leigo, cuja capacidade de transformar a sua experiência em conhecimento é garantida somente pela sua formação prévia (Bildung), não tanto como antropólogo (afinal, poucos dos Völkerkundler eram etnólogos de formação), mas como Bildungsbürger (formação clássica geral) e como homens 'iluminados' (aufgeklährt) e de ciência, capazes, por exemplo, de viver entre homens nus sem se perturbar com isso.

31 Neste ponto, o autor tinha a intenção de inserir referências bibliográficas (Nota dos Editores).
} 
no seu desenrolar temporal. Mesmo assim, tais relatos não eram considerados suficientes. Era ainda preciso 'ver' a alteridade cultural dos povos visitados com os próprios olhos (os do leitor), 'tocá-la' com as próprias mãos. Para ser deveras eficaz e autêntica, era até preciso escutar os nativos contarem seus mitos e cantarem suas canções, assim como observá-los brincar ou realizar algum ritual. Toda a praxe de Koch-Grünberg como etnógrafo, no campo e nos arquivos dos museus de Berlim e Stuttgart, precisa ser entendida com base nesta lógica.

Como já argumentamos em outra ocasião (Frank, 2005), este projeto etnográfico da Völkerkunde, o total da tarefa que aqueles etnógrafos se propuseram, afinal, era mesmo humanamente impossível de ser realizado plenamente, sob diversos aspectos, mas nem por isso eles o consideravam menos necessário. Tratava-se de uma tarefa impossível pela amplitude (na realidade, ilimitada e ilimitável) da experiência etnográfica de campo; mas, impossível também (e sobretudo) pelas estreitas limitações inerentes aos meios à disposição (textos, retórica, fotos e até mesmo os objetos etnográficos) para tentar reproduzir a sua experiência etnográfica nos seus colegas, nos estudantes e nos demais interessados em conhecer povos distintos e distantes ${ }^{32}$.

Daí tanto a facilidade que observamos em KochGrünberg de experimentar novas técnicas/tecnologias de documentação, como também a sua eterna desconfiança na eficácia de cada um delas por si só, particularmente da fotografia e da filmagem, cuja principal utilidade, como vimos, não passava de permitir uma experiência mais direta da aparência típica dos povos visitados e, em segundo lugar, da cultura material indígena, como complemento de textos, para aqueles dos seus leitores que, por acaso, não tinham como visitar os museus de Berlim, Freiburg ou Stuttgart.

Portanto, quando alguns autores atuais argumentam que, em vez de escrever 'etnografias de verdade', os Völkerkundler 'ainda' ficavam presos ao gênero (supostamente antiquado) dos relatos de viagem na apresentação (dos resultados) das suas pesquisas de campo (expedições), é imprescindível pôr este 'ainda' entre aspas, porque a persistência deste gênero literário nesta escola antropológica não se deve a qualquer incapacidade de se 'livrar' de uma tradição literária, herdada da pré-história da sua disciplina.

Como já argumentamos em outro contexto (Frank, 2005), no momento de compor "Vom Roraima zum Orinoco", por exemplo, Koch-Grünberg era agudamente ciente das limitações inerentes a esta forma de apresentação e, por isso, experimentou efetivamente um formato novo e plenamente incomum entre os seus colegas de escola. Em "Vom Roraima zum Orinoco", com os seus cinco volumes tematicamente separados, o relato da expedição (propriamente dito) foi publicado como o primeiro volume da obra, mesmo que o segundo, dedicado à mitologia, tenha aparecido antes dele. $\bigcirc$ volume que mais se aproxima de uma monografia etnográfica, no sentido atual (pós-Malinowski) deste conceito, é somente o terceiro.

Na realidade, a estrutura de "Vom Roraima zum Orinoco" oferece provas claras com relação ao conceito de trabalho etnográfico que acabamos de esboçar, justamente pela separação formal (em volumes distintos) dos diversos campos temáticos que, na sua totalidade, abrangem o que o autor (e a sua escola) considerava dados relevantes: além do contexto (geográfico e histórico) geral (detalhado no

\footnotetext{
${ }^{32}$ Como o objeto da experiência do etnógrafo no campo era a cultura dos povos visitados, uma cultura que se expressava em tudo e qualquer coisa que algum integrante destes povos fazia e falava (ou não), e ainda na mesma maneira particular (e nos contextos situacionais gerais) em que falavam e faziam as coisas e, como na geração desta cultura, influenciavam, de alguma maneira, o ambiente, a constituição biofísica, a própria mente e (como pista importante) as línguas faladas pelos nativos, a capacidade de - conscientemente - registrar e devidamente documentar a própria experiência era mesmo humanamente impossível num grau tal que até um esforço tão gigantesco de documentação, como este de Koch-Grünberg, afinal, podia cobrir (e ajudar a reconstruir) uma parte ridiculamente pequena dela. É claro que nem Koch-Grünberg acreditava mesmo reproduzir no seu leitor a própria experiência etnográfica, e é também claro que os Völkerkundler seguiam uma sistemática, particularmente nos seus textos com relação à importância (ou representatividade) relativa do observável no campo; aliás, elaborada com base na escrita paradigmática de Alexander von Humboldt. Mas, isso será explicado em outro estudo.
}

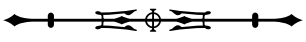


volume I), a realidade etnográfico-cultural geral (volume III), com ênfase particular na produção material e, digamos, folclórica: os mitos, as canções, as fórmulas mágicas (volume II), a linguística (volume IV) e a sua antropologia física do "Typenatlas" (volume V).

Ora, muitos já lamentaram a ênfase do projeto etnográfico de Koch-Grünberg (e dos demais Völkerkundler) na produção (material e intelectual voltada para objetos, assim como a transcrição de mitos, canções, fórmulas mágicas etc.) dos povos visitados, em 'detrimento', sobretudo, da sociologia e dos processos históricos. Tal crítica procede, pois falta - efetivamente - qualquer tentativa de uma análise mais profunda da organização social, da cosmologia ou da visão de mundo, além da sua expressão (in)direta na mitologia. Falta também a devida contextualização das culturas Macuxi, Taurepang, Yekuana etc. no contexto histórico do imperialismo capitalista e a variedade (neo)colonial que marcou o local onde aqueles povos habitavam no momento (1911-1913) em que Koch-Grünberg passou por ele (isto vale, igualmente, para "Zwei Jahre unter den Indianern"). Com relação à primeira temática, o que há neste autor são meras alusões irrefletidas a conceitos como 'tribo' e 'chefia', assim como supostas 'regras' de pertença das pessoas (patrilineares ou matrilineares) às unidades étnicas identificadas. Com relação às mudanças culturais em andamento, não pode haver dúvida de que este etnógrafo as tomou por lamentáveis perturbações da 'originalidade' ou 'autenticidade' cultural que realmente procurou. No caso dos povos acima indicados, Koch-Grünberg achou possível abstrair tais perturbações. Mas, no caso dos Wapishana, ele os considerou em um grau tão avançado que decidiu, afinal, excluir este povo do esforço etnográfico ${ }^{33}$.

Contudo, tais críticas à obra de Koch-Grünberg e da Völkerkunde em geral partem, sem dúvida, de nosso conceito atual do objetivo da antropologia, isto é, de critérios que Koch-Grünberg não compartilhou. Daí que elas pouco ajudam em nosso esforço de (re)descobrir o projeto científico deste autor (e da sua escola).

O que as críticas permitem é identificar campos de fenômenos que ficaram de fora da etnografia dos Völkerkundler, o que explica, por exemplo, a ínfima contribuição de Koch-Grünberg a obras recentes, como "Individual and Society in Guyana", de Peter Riviere, ou "Pemongon Pata", de Paulo Santilli. Mas, qualquer antropologia só pode (ou deveria) ser julgada com base naquilo que ela mesma se propõe e na verossimilhança da visão de mundo (ou filosofia) que informou esta proposta.

Foi por isso que, neste ensaio, tomamos a ênfase dada pela etnografia de Koch-Grünberg (e dos demais Völkerkundler) na produção material e intelectual dos povos visitados, nos seus objetos, nos seus mitos, nas canções e danças, nas fórmulas mágicas e nos rituais, no esforço de documentação ou reprodução fiel em fotos, filmagens, gravações e desenhos, até mesmo na obsessiva preocupação com a aquisição da cultura material e na tarefa de encaminhá-la in totum (sem alterações ou danos) a algum museu, como partes centrais de uma tarefa claramente definida, isto é, como muitos passos distintos servindo todos a uma única finalidade geral.

Há de se incluir em tudo isso, ainda, a produção de 'substitutos' a certos produtos materiais dos índios (modelos, réplicas em tamanho inferior de, por exemplo, casas e canoas), as cópias (ou reproduções esquemáticas) do grafismo dos índios em rochas, paredes, cerâmicas e na sua própria pele (pinturas e tatuagens), a transposição das suas canções em notas e partituras, assim como os desenhos dos próprios índios de paisagens, mapas, espíritos, rituais e até do próprio etnógrafo, cuja elaboração o etnógrafo estimulou ${ }^{34}$.

Acreditamos ter mostrado que isso não se devia meramente a uma obsessão privativa (e, como tal,

\footnotetext{
33 Neste ponto, o autor tinha a intenção de inserir referência a um texto de Nádia Farage, mas não indicou qual (Nota dos Editores).

${ }^{34}$ Neste ponto, o autor tinha a intenção de inserir uma figura, mas não foi possível localizá-la ou identificá-la (Nota dos Editores).
}

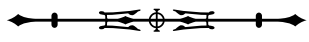


inexplicável) de Koch-Grünberg pela cultura material, em detrimento da organização social e de outros aspetos etnográficos. Há, sim, uma preocupação (eminentemente pedagógica) com o tangível, com o - sobretudo - visível, o manuseável, isto é, com a objetivação de uma cultura que se expressa em tudo o que o índio (da etnia tal-e-tal) faz (ou fez), diz ou canta, com os objetos e desenhos que ele cria, os mitos que ele conta, as suas danças e música, junto com o próprio corpo de quem faz tudo isso.

Vimos que as fotografias de Koch-Grünberg se diferenciam em retratos paisagísticos (às vezes, incluindo o próprio etnógrafo), cuja função parece ser de não substituir, mas de reforçar as descrições de paisagens sentimentais do próprio texto, um elemento indispensável de qualquer bom relato de viagem, desde os "Landschaftsgemälde" (retratos de paisagem) textuais de Alexander von Humboldt. A ênfase é em lugares (Manaus, São Gabriel, São Filipe etc., destacados no texto), mas também em paisagens, momentos e atividades de alguma importância no transcurso da própria expedição (acampamentos, cachoeiras [sendo 'desbravadas'], canoas, montanhas).

Ao lado destes, há as fotografias (individuais, raras vezes em pequenos grupos) de índios, em geral, identificados somente pelo grupo étnico ao qual pertenciam, embora alguns tenham sido identificados por seus nomes pessoais (em português ou em língua indígena) ou pela relação de parentesco com algum chefe local.

Há, sobretudo, fotos de indígenas tipificados (em alguns poucos casos, realizando alguma atividade, como caçar com zarabatana, carregar alguma coisa, preparar comida, confeccionar objetos etc.) e fotografias de objetos que, com certa frequência, são também reproduzidos em desenhos com a óbvia finalidade de realçar certas características técnicas. Como vimos, esta última categoria de fotos não pode ser considerada independente dos inúmeros desenhos (da mão do próprio etnógrafo ou, às vezes, realizados por terceiros) que, na sua ampla maioria, mostram (novamente) objetos de uso cotidiano (mas, há também esboços de pessoas e de atividades), quase sempre elaborados com base em fotos, muitas das quais são reproduzidas junto com o desenho.

Tomando todo este material em conjunto (e lembrando, ainda, que a maior parte das coisas retratadas em fotografias e desenhos foi também adquirida pelo etnógrafo e encaminhada para a Alemanha, onde foi depositada em algum museu), acreditamos não restar dúvida de que a função da sua elaboração, mais particularmente, de que a razão da sua inclusão/ reprodução nos relatos de viagem deste autor foi exatamente a de permitir ao leitor uma experiência tão completa e imediata possível de algo que, na sua soma, constituiu o verdadeiro objeto de interesse do etnógrafo.

Mas, afinal, que experiência foi essa?

Uma experiência de contato e convivência direta com índios amazônicos, por certo; mas, como mostra a obra de Koch-Grünberg, também e sobretudo, a experiência de algo que estes índios expressavam em tudo o que produziam, faziam e sabiam falar, e que estava (e ficaria para sempre) presente nos seus objetos, suas atividades e seus pronunciamentos - não importa a natureza própria, particular e específica destes objetos, atividades e pronunciamentos!

Eis a diferença decisiva entre a etnografia dos Völkerkundler e a tradição etnográfica atualmente universal (que chamamos de logocêntrica). A etnografia de Koch-Grünberg (e dos demais Völkerkundler) não procurava ilustrar tese (ou teoria) nenhuma, além da que tudo o que os índios amazônicos (ou qualquer outro povo humano) produziam, faziam, falavam (e pensavam) documentava, igualmente bem (no sentido de representar ou conter), a sua constituição cultural específica. Para Koch-Grünberg (e os demais Völkerkundler), a cultura não era nada que precisasse (ou pudesse) ser descoberto. Ela não existiria por detrás das suas próprias manifestações empíricas (e, por isso, também não precisaria ser 'traduzida', como se diz hoje). A cultura dos Völkerkundler só pode ser experimentada (nas suas manifestações). Mas, justamente por isso, qualquer manifestação cultural servia igualmente bem ao propósito destes etnógrafos. 
A cultura de um povo estaria em (da particularidade/ singularidade a) tudo o que os seus integrantes fazem e dizem, impregnando (e permanecendo para sempre em) todos os 'produtos' da sua atuação (inclusive as suas falas e os seus gestos). Eis a razão da paixão dos Völkerkundler pelas etnografica, pela mitologia e pelos rituais; mas, eis também a importância que eles atribuíam aos museus etnográficos.

Se Karl von den Steinen achou que "sem museu não dá" (para ensinar antropologia), e nem para ser ou permanecer Völkerkundler, para ele, o museu (e somente o museu) permitia fazer experiências etnográficas imediatas, sem qualquer necessidade de viajar! Ou seja, longe de se considerar meros tradutores de culturas para um público (ocidental) incapaz de entender o (culturalmente) 'outro' sem explicação, os Völkerkundler se consideravam facilitadores de uma experiência (e de um conhecimento derivado dela) teoricamente possível para qualquer um (de bom senso, é claro), mas, na prática, limitada a poucos, e ainda ameaçada, como experiência-possibilidade, pelo suposto desaparecimento das culturas não-ocidentais, que todos os Völkerkundler consideravam inevitável em razão da própria natureza da civilização ocidental, que orgulhava a alguns e que era motivo para lamento de outros.

\section{REFERÊNCIAS}

BUCHHEIT, Klaus Peter. Die Verkettung der Dinge: Stil und Diagnose im Schreiben Adolf Bastians. Münster: Lit Verlag, 2005.

FIEDERMUTZ-LAUN, Annemarie. Der kulturhistorische Gedanke bei Adolf Bastian: Systematisierung und Darstellung der Theorie und Methode mit dem Versuch einer Berwertung des Kulturhistorischen Gehaltes auf dieser Grundlage. Wiesbaden: F. Steiner, 1970.

FRANK, Erwin. Viajar é preciso: Theodor Koch-Grünberg e a Völkerkunde alemã do século XIX. Revista de Antropologia, v. 48, n. 2, p. 559-584, 2005.

GALUCIO, Ana Vilacy. Theodor Koch-Grünberg: documentando culturas indígenas no início do século $X X$. Boletim do Museu Paraense Emílio Goeldi. Ciências Humanas, v. 4, n. 3, p. 553 556, 2009.

KOCH-GRÜNBERG, Theodor. Walzenaufnahmen aus Brasilien 1911-1913. Berlim: Berliner Phonogramm-Archiv, 2006a. (Historische Klangdokumente, 3).

KOCH-GRÜNBERG, Theodor. Do Roraima ao Orinoco. Observações de uma viagem pelo norte do Brasil e pela Venezuela durante os anos de 1911 a 1913. São Paulo: UNESP/nstituto Martius Staden, 2006b. v. 1.

KOCH-GRÜNBERG, Theodor. Dois anos entre os indígenas. Viagens no noroeste do Brasil (1903-1905). Manaus: Universidade Federal do Amazonas/Faculdade Salesiana Dom Bosco, 2005.

KRAUS, Michael. Bildungsbürger im Urwald: Die deutsche ethnologische Amazonien-forschung (1884-1929). Marburg: Curupira, 2004. 